\title{
The Place of Classical Guitar Instrument in Turkey and an Overview of Turkish Classical Guitarists
}

\author{
Taner Ulucay \\ Erzincan Binali Yildirim University, Erzincan, Turkey \\ E-mail: ulucay44@gmail.com
}

\begin{abstract}
The aim of this study is to give information about the place of the classical guitar instrument in Turkish music culture and also provide information about Turkish classical guitar artists. Content analysis method was used in the study. The data was obtained through literature review. The data obtained were compiled and interpreted. The condition of classical guitar instrument in our music system within the ninety six years since the proclamation of the Republic has been discussed in the study. In addition, examples were given about classical guitarists who lived or still live in post-republican Anatolia. The results of the study provide a comprehensive understanding of the status of classical guitar in Anatolian music style and its role in music education system.
\end{abstract}

Keywords: Classical Guitar, Republic of Turkey, Turkish Classical Guitar Artists

DOI: $10.7176 / \mathrm{JSTR} / 6-08-07$

\section{Introduction}

The first examples that can be supposed as the ancestors of classical guitar are found in the ancient Egyptian wall paintings, in the Hittite stone reliefs and on the sculptures from the Ancient Greek period (Uluocak, 2015). On the other hand, the first examples of modern guitar emerged in Spain in the 13th century with the names 'guitarra latina-guitarra morisca'. Guitar started to be used as an instrument in the songs in Spain, Italy, France and England during the Renaissance period (15th-16th century), and wandering poets employed this "renaissance guitar" in their songs. Guitar, which also evolved in the Baroque and Romantic periods, took its modern form as Torres Guitar in Spain in the 19th century.

Classical guitar has gained its modern 6 string form as a result of the evolutionary process that it underwent especially in the late 17 th century and 18th century. Both the design of the instrument has improved and the guitar literature has been enriched in this process.

In 1799 Fernando Frandiere published the book 'Arte de Tocar la Guitarra Espanola Por Musica'. In the theoretical sense, this book can be considered as the first example. On the other hand, it is evident that there are many major names from the 18th Century Romantic Period. F. Carulli (1740-1841), M. Carcassi (1792-1853), D. Aguado (1784-1849), F. Sor (1778-1839) and M. Giulliani (1781-1829) are the most important guitar performers of this period (Küçükay, 1992).

There is no official source to prove the existence of classical guitar in the Ottoman Empire. However, it is assumed that guitar was used, even if just a bit, in Ottoman music especially in III. Selim and II. Mahmud periods in which the westernization movements took place.

With the proclamation of the Republic of Turkey, Music Teachers' School was established in 1924 and music education entered into the official education system. But even within this structure, the presence of classical guitar was only felt in the 1970s. Guitar was included in the educational curriculum in 197374 academic year. In these years, the instrument which was only regarded as a school instrument for the university undergraduate period was accepted as a main musical instrument in 1985 and took its place amongst others.

When we take the integration process of classical guitar in university education into consideration, we see that Ahmet Kanneci, from the music club of Middle East Technical University, was the first to give guitar lessons. Kanneci, then, turned his experiences into a book (Erim-Yöndem, 2007:93).

Recently, the number of guitar educators has increased and classical guitar has taken its place as an individual instrument and become an orchestra course in music education departments. Classical guitar education is also given in the vocational high schools of fine arts. Moreover, guitar education is also given individually or collectively in some amateur institutions that deliver music education. However, these institutions can sometimes be connected to national education system or can be within some private institutions. 


\section{Aim}

The aim of this study is to determine the status of the guitar instrument in the Republic of Turkey and provide information about Turkish guitarists who have contributed to guitar literature.

\section{Importance}

This study is important in that it provides information in terms of the use of classical guitar in Turkey after the proclamation of the Republic. There is information about classical guitar, guitarists and classical guitar usage methods.

\section{Method}

Content analysis method was used in the study. The data was obtained through literature review. The data obtained were compiled and interpreted.

\section{Findings}

\section{Turkish Guitarists in Anatolia after the Proclamation of the Republic}

In this section, the chronological list of the Turkish guitarists since the proclamation of the Republic is presented. It is aimed to determine the place of classical guitar concept in Anatolia in the light of the lives and works of those guitarists.

Andrea Paleologos (1911-1997), Ziya Aydıntan (1905-1982), Can Aybars (1917-1999) and Mazhar Reşit Ertüzün are prominent names who are not alive today but served as both guitarist and classical guitar instructors in Turkey after the proclamation of the Republic (Kanneci; 2001). Erkan Oğur (1954-), (Erdem Sökmen (1957-), Ahmet Kanneci (1957-), Sefa Yeprem (1974-) are the leading names as exapmles of prominent guitarists. The common characteristic of these guitarists is that they are both guitar performers and educators.

\section{Andrea Paleologos (1911-1997)}

He was a child of musician parents. He received mandolin education at age seven and violin at age nine. He played mandolin and violin in many concerts when he was young. He listened to a classical guitar record at a friend's house one day, and since then classical guitar had an important place in his life (Mazmanian, 1960). Fascinated by the timbre of the instrument, Paleologos made a new decision about his future and from that time on he devoted himself to the classical guitar. As he mentioned, he allocated five hours a day and started to practice the methods and works of F. Carulli and M. Carcassi in the first hand, and then the works of D. Aguado, F. Sor, N. Coste, H. Albert and F. Tarrega (Uluocak 2015 qtd. from Mazmanian, 1969). He started to perform guitar concerts in Istanbul and Athens after 1934. Paleologos is considered to be the first classical guitarist and guitar educator in the history of the Republic (Elmas, 1986). Until he moved to Athens in 1964, he lived as an active musician and educator in Turkey.

\section{Ziya Aydıntan (1905-1982)}

Aydıntan, who was born in Van in 1905, started his music education with a musician named İlya İrinopules at a quite young age (Say, 1992: 128). He is one of the first graduates of the Music Teachers' School. He studied violin, viola and mandolin at Music Teachers' School and was appointed as a music teacher in Trabzon. After a few years in this city, Aydintan was appointed to Istanbul in the 1930s and became interested in the classical guitar. During his stay in Istanbul, Aydintan had the opportunity to take classical guitar lessons from the master Andrea Paleologos (Elmas, 1986). Then, he moved to Ankara and started to give classical guitar lessons in addition to teaching music and played and important role in introducing this instrument there (Uluocak, 2015). Ziya Aydintan was one of the pioneering guitarists and music educators who achieved many firsts with regards toclassical guitar in Turkey. He trained many trainees since 1950s in Ankara and also constituted the first orchestra known in Turkey (Kanneci, 2001: 20). He is the author of the first Turkish classical guitar training book 'Guitar Method I-II'.

Aydıntan also wrote a harmony book with guitar practice in order to strengthen the theoretical knowledge of classical guitar learners. This book, titled Classical Harmony (Guitar Applied), has reached to the present as an influental example that proves the power of the classical guitar as a harmony instrument. It also proves that harmony learning can be applied successfully through classical guitar (Uluocak, 2015).

\section{Can Aybars (1917-1999)}

Can Aybars was born in Saratof, a city in the Russian Republic of Tatarstan, and immigrated to Istanbul with his family at an early age. He completed his primary education in Ankara. Aybars returned to Istanbul for his secondary and high school education and was admitted to Darüşşafaka and acquired his first classical guitar knowledge in these years (Uluocak, 2015). After high school education in Istanbul,

57 I $P$ a g e 
Aybars started his university education in Ankara and always kept his guitar close at hand in his years in Ankara University, Faculty of Political Sciences (Uluocak, 2015).

Although he chose a different field of study at the university, he preserved his guitarist and educator identities and made important contributions to guitar literature.

Aybars' works can be evaluated in two main sections. The first is classical guitar education and the second is the arrangements amongst Turkish music pieces which he made for classical guitar. Aybars, who believed that Turkish music melodies should be arranged by classical guitar, arranged many pieces including the Turkish National Anthem, Rumeli's Mountains and some classical Turkish music works, but none of these arrangements was published. Aybars, one of the pioneers of classical guitar education in the first fifty years of the Republic, also became one of the most well-known classical guitar educators in Ankara like Ziya Aydintan (Uluocak, 2015).

\section{Mazhar Reşit Ertüzün (1917-2010)}

During his stay in Istanbul, Mazhar Reşit Ertüzün had the chance to take classical guitar lessons from Andrea Paleologos and used the Tarrega technique. After his university education in Ankara University, Faculty of Political Sciences (Civil Service), Ertüzün started to be greatly mentioned together with Erdek town where he served as district governor for many years and made great contributions to the discovery and promotion of the historical, cultural and archaeological accumulation of the town. He has also written many books on the history and archeology of this town. During his busy life, Ertüzün always kept his classical guitar with him, and educated many students from time to time.

\section{Erkan Oğur (1954- )}

Mehmet Erkan Oğur was born in 1954 in Elazığ. Oğur went in for music by playing violin, baglama, flute and metal mandolin from the age of 4 . His primary school music teacher who encouraged him to perform Folk Music said: "He could play almost all the musical instruments of this region when he finished primary school." After completing his high school education in Ankara, Oğur started his university life in Ankara University at the Physics Department in the Faculty of Science, and continued his education in University of Munich at the Physics Engineering Department. Then, he decided to become a musician, returned to Turkey and studied Music Theory in Istanbul State Conservatory (wikipedia).

The artist mainly uses kopuz or baglama, oud, e-bow, fretless guitar, classical guitar and his voice in his works, and is able to play classical guitar, electric guitar and jazz guitar at virtuoso level. The greatest contribution of the artist to Anatolian music culture was the invention of the fretless guitar which he produced in 1976. Apart from all these, he has successfully played many instruments in his albums. Most recently, he has made two improvised jazz experiments in an album with Telvin Trio. His album "Fretless" was selected as the creative album of the year in Europe. The same album was then published in Turkey titled "A Lifetime Guest". As a performer of Turkish music, Oğur has taken his place in world music literature as a musician to evolve the fretless guitar and fretless baglama. In 1984, Oğur accompanied the "Güllerin İçinden" song of the band MFÖ with his fretless guitar (wikipedia).

Erkan Oğur still continues to work with various worthy musicians such as Bülent Ortaçgil, Tarkan Tevetoğlu, Ismail Hakkı Demircioğlu.

\section{Erdem Sökmen (1957- )}

After receiving private guitar lessons from Raffi Arslanyan, Erdem Sökmen studied composition and guitar at Mimar Sinan University. In 1986, he founded the classical guitar department in Istanbul University State Conservatory, and received the title of proficiency in art. It is also known that Kenan Doğulu received classical guitar lessons from Erdem Sökmen at the conservatory. He also founded a group called Pasifflora. It is a Latin-jazz group composed of worthy musicians such as Levent Altındağ, Eylem Pelit, Volkan Öktem, Serkan Özyılmaz and Şenova Ülker (kadrikarahan.net).

Erdem Sökmen views life in his own words as follows: "After losing many of my relatives one after another, I got the feeling that life was really short and shouldn't be taken too seriously. I don't like to be too ambitious and to compete with others. I want to spend enough time with my friends and fellows, and to produce quality things as much as I can in professional sense".

In 1993, he edited and played the guitar parties of the song "Tuana" for Levent Yüksel which was written by Sezen Aksu, and composed by Paco De Lucia. He still plays the classical guitar parties of many albums, and works as a guitar instructor in various universities and private educational institutions in Istanbul. 


\section{Ahmet Kanneci (1957- )}

Born in 1957, Ahmet Kanneci started his theoretical education in music with his teacher Turgay ERDENER who was one of the leading composers in Turkey. He received harmony and counterpoint lessons from Istemihan TAVILOGLU and Ali SEVGI. After meeting Julian BYZANTINE in 1977, he concentrated his studies and works completely on classical guitar. After graduating from METU Faculty of Architecture, he got a scholarship granted by the Government of Spain and studied in the same class with Jose TOMAS, and successfully completed his education in Oscar Espla de Alicante in Conservatorio Superior de Musica with "First Prize". He also received the "First Prize" from the State Conservatory of Perpignan, France. He had the chance to play with his favourite virtuoso Aliri DIAZ, from whom he received lessons for 30 years. After completing his studies in Europe, Kanneci returned to Turkey and established guitar departments in four different conservatories and universities. In 1993, he went to USA for a Fulbright Research Fellowship.

The awards received by the artist are as follows:

- "Lifetime Achievement in Art" by Fulbright Commission,

- “Appreciation” by METU Senate,

- "Honorary Doctorate" by Harran University and Isparta Süleyman Demirel University,

- “Art Award" by Hacettepe University.

- "The Guitarist of the Year Award" organized for the first time by Y1ldı Technical University.

- Andres Segovia Medal of Honor in 2010 (kanneci.org).

\section{Sefa Yeprem (1974- )}

Sefa Yeprem was born in Ankara in 1974 and he successfully completed his primary and secondary education in Istanbul. Yeprem started his music education in 1983 and studied classical, acoustic, electric and bass guitar. Then, he started to study music education in Marmara University Atatürk Education Faculty in 1991. In addition to classical guitar, he has worked on Flamenco and Latin music.

Yeprem graduated from Marmara University Atatürk Faculty of Education Department of Music in 1995. In the same year, he was qualified as a postgraduate student in Marmara University Institute of Science and Technology. Yeprem completed his postgraduate education successfully in 1998 with his thesis titled "Flamenco Styles and Their Usability in Guitar Education", and since then has given many concerts in Turkey and abroad and taken part in various scientific and artistic activities.

Many of his works are appreciated and performed abroad. His works such as "Suite de la Caloriferre", "Midnight", "Café turc" are broadcasted by "Les Productions d'OZ" in Canada and are also performed by many guitarists in various countries. His "Folk Song Arrangements for Classical Guitars" has been performed in Serbia by Mustafa Cirika and Milan Mitic. The abovementioned works also appeared in New York Guitar Seminar in 2012. Yeprem made a three guitar arrangement for Sadi Iş1lay's piece "Sultan-1 Yegâh Sirto in 1993 and it was performed both by the band "Atlanta Guitar Guild" in Atlanta and by "Kennesaw State University Classical Guitar Ensemble". Yeprem's works, written for solo guitar, "Lights of Truth" and "Rain" were performed by the guitarist Mary Akerman at Kennesaw State University (Atlanta), USA in 2012. "Lights of Truth" was also performed by Andrew Eubanks in 2012.

Yeprem has conducted a research titled "Flamenco Art and Guitar" consisting of a combination of his postgraduate theses and special compositions. The aim of this research is to give a new perspective to basic guitar education based on the structure of Flamenco Art.

In 2007, he was appointed as an assistant professor in Istanbul University, Faculty of Theology, Department of Turkish Religious Music. On January 8, 2008, Yeprem received the title of Associate Professor in "Music" branch of "Fine Arts". In February 2009, he was appointed to Kocaeli University, Faculty of Fine Arts, the Department of Musicology. He worked as the head of the Music Department and the Department of Musicology between 2009-2012. In 2013, his book "Hymns for Classical Guitar "was published by Bemol Music Publications. The second edition of his work "Guitar Modal Expansions and Chord Structures" was also published by Bemol Music Publications in 2013. In January 2013, he has been appointed as an associate professor to Marmara University, Faculty of Theology, Department of Turkish Religious Music. He has received the "Professor" title in the same department in September 2013. (sefayeprem.com).

Yeprem is still a faculty member in Marmara University, Faculty of Theology, Department of Turkish Religious Music. 


\section{RESULTS}

- Turkish guitarists are recognized and valued both in Turkey and in different countries.

- Many of the Turkish guitarists serve both as musicians and educators.

- Our guitarists play classical music, Flamenco music and Turkish music motifs with their instruments.

- It is seen that Turkish guitarists also teach in the universities.

- It is seen that Turkish guitarists have interpretation, editing, and production characteristics.

- It is approved that the fretless guitar, which holds a significant place in world music culture, was found, produced and used first by Turkish guitarist Erkan OĞUR.

\section{References}

ELMAS, Y. (1986). Müzik tarihinde gitarın biçim evrimi. Yayımlanmamış Doktora Tezi, Marmara Üniversitesi Fen Bilimleri Enstitüsü, İSTANBUL.

ERIM, A., YÖNDEM, S., (2007). Türkiye'de Klasik Gitar Eğitiminde Kullanılan Başlangıç Metodlarından Bazılarının Öğretme-Öğrenme Süreçleri Açısından Karşılaştırılması. Abant İzzet Baysal Üniversitesi Sosyal Bilimler Enstitüsü Dergisi Cilt:1, Sayı:14 (90-109), BOLU.

KANNECI, A. (2001). Gitar için beste yapmış türk bestecilerinin eğitimi ve yapıtlarının uluslar arası gitar repertuarındaki yeri. Yayınlanmamış Yüksek Lisans Tezi, Gazi Üniversitesi, Eğitim Bilimleri Enstitüsü, ANKARA.

KÜÇÜKAY, B. (1992) Klasik Gitar İçin Başlangıç Metodu. Evrensel Yayınevi. ANKARA.

MAZMANIAN, V. (Mart-Nisan 1960). The guitar in İstanbul, Guitar News, 52, 19-20. İSTANBUL

SAY, A (1992). Müzik Ansiklopedisi.: Müzik Ansiklopedisi Yayınları. ANKARA

ULUOCAK, S. Türkiye'de Cumhuriyetin İlk Elli Yılında Klasik Gitar Eğitimi: Paleologos ve Öğrencileri, (2015), Sahne ve Müzik Eğitim - Araştırma Dergisi, Cilt:1, Sayı:1,

https://tr.wikipedia.org/wiki/Erkan_O\%C4\%9Fur

http://www.kadrikarahan.net/erdemsokmen.htm

http://www.kanneci.org/yeni/

http://www.safayeprem.com/biyografi/ 